\title{
Influence of Variable Milk Quality Premiums on Observed Milk Quality
}

\author{
C. Nightingale, ${ }^{* 1,2}$ K. Dhuyvetter, $†$ R. Mitchell, ${ }^{*}$ and Y. Schukken* \\ *Quality Milk Production Services, College of Veterinary Medicine, Cornell University, Ithaca, NY 14850 \\ †Department of Agricultural Economics, Kansas State University, Manhattan, Kansas 66506
}

\begin{abstract}
The objective of this study was to evaluate a premium program for very high quality milk in a US cooperative. Data were available on a monthly basis from a large US milk cooperative from April 1998 through December 2005 . The data set consisted of 36,930 observations representing producer-months. The actual amount of the low bulk tank somatic cell count (BTSCC) premium varied from $\$ 0.15$ per hundred pounds (cwt.) of milk to $\$ 1.00 /$ cwt. with steps in between of $\$ 0.50$ and $\$ 0.60$ per cwt. of milk during the data collection period. Data analysis was done to evaluate the impact of the premium program on average BTSCC and on the probability of a producer to ship milk with $<100,000$ cells $/ \mathrm{mL}$ in a given month. The results showed a strong effect of the premium program on both the average BTSCC and the probability of producing milk with very low BTSCC. On average, the BTSCC of all the milk in the cooperative was reduced by 22,000 cells during the high premium period. The probability of producing milk with BTSCC $<100,000$ doubled during some months of the high premium period from 4 to $8 \%$, and an associated $10 \%$ increase in probability to produce milk below 200,000 cells $/ \mathrm{mL}$ was observed. The data clearly indicate that premium offerings for very high quality milk affect the overall milk quality in the population affected by the premium. Producers responded to the high premiums and the overall impact on milk quality was substantial. We argue that the combination of a penalty program for high BTSCC milk with a premium program for very high quality milk (low BTSCC) provides a strong incentive for improvement of milk quality.
\end{abstract}

Key words: bulk tank somatic cell count, milk quality regulations, premium policy

\section{INTRODUCTION}

Mastitis, defined as an inflammation of the udder, is usually caused by a bacterial infection. This inflamma-

Received August 13, 2007.

Accepted November 21, 2007.

${ }^{1}$ Corresponding author: compgain@gmail.com

${ }^{2}$ Current address: Cargill Inc., Minneapolis, MN. tion results in elevated SCC, which interferes with milk production in the udder (Schukken et al., 1990; Hortet and Seegers, 1998; Wilson et al., 2004). Mastitis is considered to be the most frequent and most costly production disease in dairy herds of developed countries (Seegers et al., 2003). Elevated SCC leads to decreased raw milk quality, which is the determining factor for its processing value. Elevated SCC was associated with decreased shelf life of dairy products, edible food loss, and lower cheese yields (Klei et al., 1998; Barbano et al., 2006).

International agriculture policy allows exclusion of products produced in the United States from entering the global supply chain due to a lower level of stringency compared with competing countries. Current US somatic cell regulations allow an upper limit of 750,000 cell $\mathrm{s} / \mathrm{mL}$, whereas other contributors to the world market have moved to an upper limit of 400,000 cells $/ \mathrm{mL}$ (Canada has moved to 500,000 cells $/ \mathrm{mL}$ ) over the last decade (Sargeant et al., 1998). Poor milk hygiene and more specifically, high SCC, have implications on milk's structure, processing value, shelf life, and edible food loss (Barbano et al., 2006), and indirectly on consumer concerns with regard to human health, bacterial contamination, and antimicrobial residues (Ruegg and Tabone, 2000; Saville et al., 2000; Jayarao and Henning, 2001; Hogan, 2005; Straley et al., 2006). These monetary and consumer confidence losses to the industry are eventually transferred to the dairy producer in the form of reduced milk markets and lower milk prices. Penalties in the form of temporary exclusion from a saleable milk market or quality deductions from the producer's milk check are commonplace (Schukken et al., 1992a), but sudden changes in the penalty program were expected to be disruptive to the market (Adkinson et al., 2001). Premium policies would motivate farmers to produce high quality milk without providing a potential disruption to the milk supply. Although these premium offerings may present producers with significant monetary incentives to maintain bulk tank SCC (BTSCC) at or below the premium cut-off level (i.e., 100,000 or fewer cells $/ \mathrm{mL}$ ), the degree that this inducement affects management and overall milk quality is currently unknown. 
A simulation study performed on Dutch and Canadian milk quality data (Schukken et al., 1990, 1992b) suggests that herds with a low annual BTSCC level are more likely to stay within that level, whereas herds with a high annual BTSCC are more variable, and may be induced to lower the BTSCC level. These simulation studies provided an initial indication that economic incentives may play a major role in reducing the overall population BTSCC (Schukken et al., 1990), where the population would be any group of farms that fall under the same premium policy.

To date no work has been done to demonstrate how producers are influenced by various premium levels. By evaluating premium offerings in combination with milk quality and milk quantity data from a large US milk cooperative, we were able to explore and quantitatively evaluate this relationship. This study was conducted to 1) describe milk quality over time and during a variable BTSCC premium program in a cooperative, and 2) statistically model the impact that premium programs have on BTSCC in the total milk supply of the cooperative.

\section{MATERIALS AND METHODS}

\section{Study Population}

Monthly data were collected from Upstate-Niagara Cooperative Inc. (Buffalo, NY), a large US milk cooperative, from April 1998 through December 2005 (36,930 observations). Milk processed by this cooperative represented approximately $1 \%$ of the milk produced in the United States during the data collection period. Included in the data set were a unique anonymous producer identification, the zip code of the producer farm, volume of milk shipped $(\mathrm{kg} / \mathrm{mo})$, component values including butterfat, protein, lactose, and other solids; SCC, bacteria counts by plate loop count, and the presence or absence of an inhibitor residue (also known as antibiotic residue). All milk quality and component analyses were performed by the milk cooperative's inhouse laboratory. The laboratory used a Bentley Somacount SCC analyzer (Bentley Instruments, Chaska, $\mathrm{MN}$ ), and bacteria counts were performed using the standard plate count method. The laboratory is certified by the Food and Drug Administration.

The variables butterfat, protein, lactose, and other solids were omitted from further analysis because regulation is independent of milk component breakdown. Freezing point measures to evaluate the water content of milk were also not relevant for this study. Observations were omitted for missing values in any category being analyzed.

Milk quality premium offerings were also collected and recorded for the same test period. This cooperative has had an aggressive but variable low BTSCC premium policy, which allowed us to evaluate the impact of this premium on BTSCC in milk produced for this cooperative over time. The actual amount of the low BTSCC premium varied from $\$ 0.15$ to $\$ 1.00$ per cwt. of milk during the data collection period.

\section{Data and Statistical Analyses}

All data were analyzed using SAS software (SAS Institute, 2006). Descriptive analysis of milk variables by month was performed using PROC MEANS of SAS. When variables were analyzed by producer-month, there was a maximum of 93 (April 1998-December 2005) monthly samples per individual producer. The weighted BTSCC (WBTSCC) was calculated on samples from individual milk shipments and was weighted or adjusted based on each producer's level of milk production. The WBTSCC for all milking cows in a herd should approximate the BTSCC and is calculated as WBTSCC $=\left(\right.$ BTSCC $\left.\times \mathrm{kg}_{\text {producer-month }}\right) / \Sigma \mathrm{kg}_{\text {month }}$.

To estimate the impact of premium programs on the subsequent milk quality, a PROC MIXED (multivariate random effect regression, SAS Institute, 2006) model was developed to test the fixed effects of seasonality, pounds of milk produced, and the premium structure in a given time period. The linear mixed model also incorporates random effects for producer to account for herd variability and is calculated as

$$
\begin{aligned}
& \text { BTSCC }=\text { intercept }+ \text { seasonality }+ \text { milk }(\mathrm{kg}) \\
& + \text { premium code }+ \text { producer }(\text { random })+\mathrm{E}
\end{aligned}
$$

where seasonality is a regression term for a sine function and a cosine function modeling annual variation in BTSCC. The function for this was

$$
\beta_{1} \operatorname{Sin}[2 \pi \times(\operatorname{month} / 12)]+\beta_{2} \operatorname{Cos}[2 \pi \times(\operatorname{month} / 12)]
$$

and has been described previously (Schukken et al., 1992b). The 2 parameters $\left(\beta_{1}\right.$ and $\left.\beta_{2}\right)$ are to be estimated from the data; month refers to a number from 1 to 12 , coding January to December. The term "milk" represents the milk produced by a dairy on a monthly basis $(\mathrm{kg})$. Premium code is a categorical variable coding for baseline (before February 1999 with a quality premium of $\$ 0.15$ for the lowest BTSCC bracket), $\$ 0.50 /$ cwt. for February 1999 to July 2001, \$1.00/cwt. for August 2001 to July 2002 , and $\$ 0.60 /$ cwt. thereafter. Producer represents a random effect term, and $\mathrm{E}$ is the residual error term, assumed to be distributed normally (Grohn et al., 1999).

The above-described premium values are the maximum premiums offered by the milk plant during the 
Table 1. Descriptive analysis of cooperative raw milk testing variables by year ${ }^{1}$

\begin{tabular}{|c|c|c|c|c|c|c|c|}
\hline \multirow[b]{2}{*}{ Year } & \multirow[b]{2}{*}{$\mathrm{n}^{2}$} & \multicolumn{2}{|c|}{ Milk yield, kg } & \multicolumn{2}{|c|}{ BTSCC } & \multicolumn{2}{|c|}{ WBTSCC } \\
\hline & & Mean & SD & Mean & $\mathrm{SD}$ & Mean & SD \\
\hline 1998 & 4,353 & 99,796 & 136,912 & 356 & 178 & 306 & 395 \\
\hline 1999 & 5,579 & 105,341 & 145,992 & 353 & 177 & 295 & 378 \\
\hline 2000 & 5,244 & 84,966 & 106,391 & 358 & 182 & 302 & 361 \\
\hline 2001 & 4,893 & 90,359 & 120,150 & 321 & 166 & 272 & 343 \\
\hline 2002 & 4,660 & 97,591 & 138,969 & 335 & 180 & 279 & 370 \\
\hline 2003 & 4,374 & 101,867 & 156,633 & 325 & 179 & 261 & 366 \\
\hline 2004 & 4,038 & 109,681 & 167,251 & 304 & 169 & 242 & 334 \\
\hline 2005 & 3,843 & 117,656 & 176,119 & 316 & 179 & 249 & 334 \\
\hline Total & 36,930 & 100,198 & 143,686 & 335 & 177 & 278 & 362 \\
\hline
\end{tabular}

${ }^{1}$ Number of observations, mean, and SD are reported for milk yield, bulk tank SCC (BTSCC, thousands), and weighted BTSCC (WBTSCC, thousands).

${ }^{2} \mathrm{n}$ represents the number of producer-months.

study period, and available for milk produced with BTSCC $<100,000$ cells $/ \mathrm{mL}$. The premium structure also offers premiums for classifications of milk that fall into BTSCC categories from 100,000 to 150,000 cells $/ \mathrm{mL}$, 150,000 to 200,000 cells $/ \mathrm{mL}$, and 200,000 to 300,000 cells $/ \mathrm{mL}$. The dollar value for the premium at those levels halves at each step up. We were particularly interested in modeling the maximum premium offering for this analysis. It was our assumption that farmers were primarily attracted by the dollar value in the highest premium category.

Data were further analyzed to estimate the probability that a producer sold milk in a given month with a BTSCC in the category of $<100,000$ cells $/ \mathrm{mL}$. The following logistic regression was used to model this probability:

$$
\begin{gathered}
\text { Logit }[\text { prob }(\mathrm{BTSCC}<100)]=\text { intercept }+ \text { seasonality } \\
+ \text { milk }(\mathrm{kg})+\text { premium code }+\mathrm{RE}
\end{gathered}
$$

where logit[prob(BTSCC $<100]$ is the probability that a farm produced milk in a given month with BTSCC $<100,000$ cells $/ \mathrm{mL}$. The explanation of the regression terms is the same as in the mixed model above. The complex error term now contains a within-herd correlation that is estimated using the general estimation equation methodology (Schukken et al., 2003). For all analysis, a $P$-value of $<0.05$ was deemed statistically significant. Analyses were performed in PROC GLMMIX of SAS (SAS Institute, 2006).

We further interpreted the model predictions on the influence of reducing population-wide cell counts by plotting mean BTSCC and mean predicted BTSCC for the study period with the highest premium offering (August 2001 to August 2002) with mean BTSCC from the previous year's data (August 2000 to August 2001).

\section{RESULTS}

The mean, number ( $\mathrm{n}$, sample size), and standard deviation for BTSCC, WBTSCC, and milk production (kg) for the producers in the cooperative are shown in Table 1 . The data are presented by year. Figure 1 presents a time-series plot of mean BTSCC and mean WBTSCC. As expected, BTSCC followed a seasonal pattern with a peak in late summer and fall and lower values in winter. Similar seasonal effects have been reported before (Sargeant et al., 1998). Figure 1 illustrates that mean BTSCC and mean WBTSCC follow the same trend. Monthly mean WBTSCC allowed visualization of trends in the overall milk supply, whereas mean BTSCC allowed visualization of trends at the producer level. Weighted BTSCC was lower compared with unweighted BTSCC, indicating that larger dairies tend to produce milk with a lower cell count. Figure 2 shows the complete data set plotted as BTSCC vs. kilograms of milk shipped in a given month. The vast majority $(89 \%)$ of producer-month observations are between a BTSCC level of 100,000 and 600,000 cells $/ \mathrm{mL}$. The figure shows that smaller amounts of milk shipped were associated with the highest and lowest BTSCC.

A very low average BTSCC was observed in March 2004. Although it is tempting to assume that a measurement error occurred in this month, none of the individual observations could be classified as outliers. Because all observations are from one laboratory, it is possible that a scaling of the equipment is partly responsible for these unusually low observations. The data from this month were kept in all analyses but indicated separately in graphical representations.

The final mixed-model linear regression results are shown in Table 2. Significant variables include seasonality (2 variables), kilograms of milk produced, and BTSCC premium at all levels. Compared with baseline 


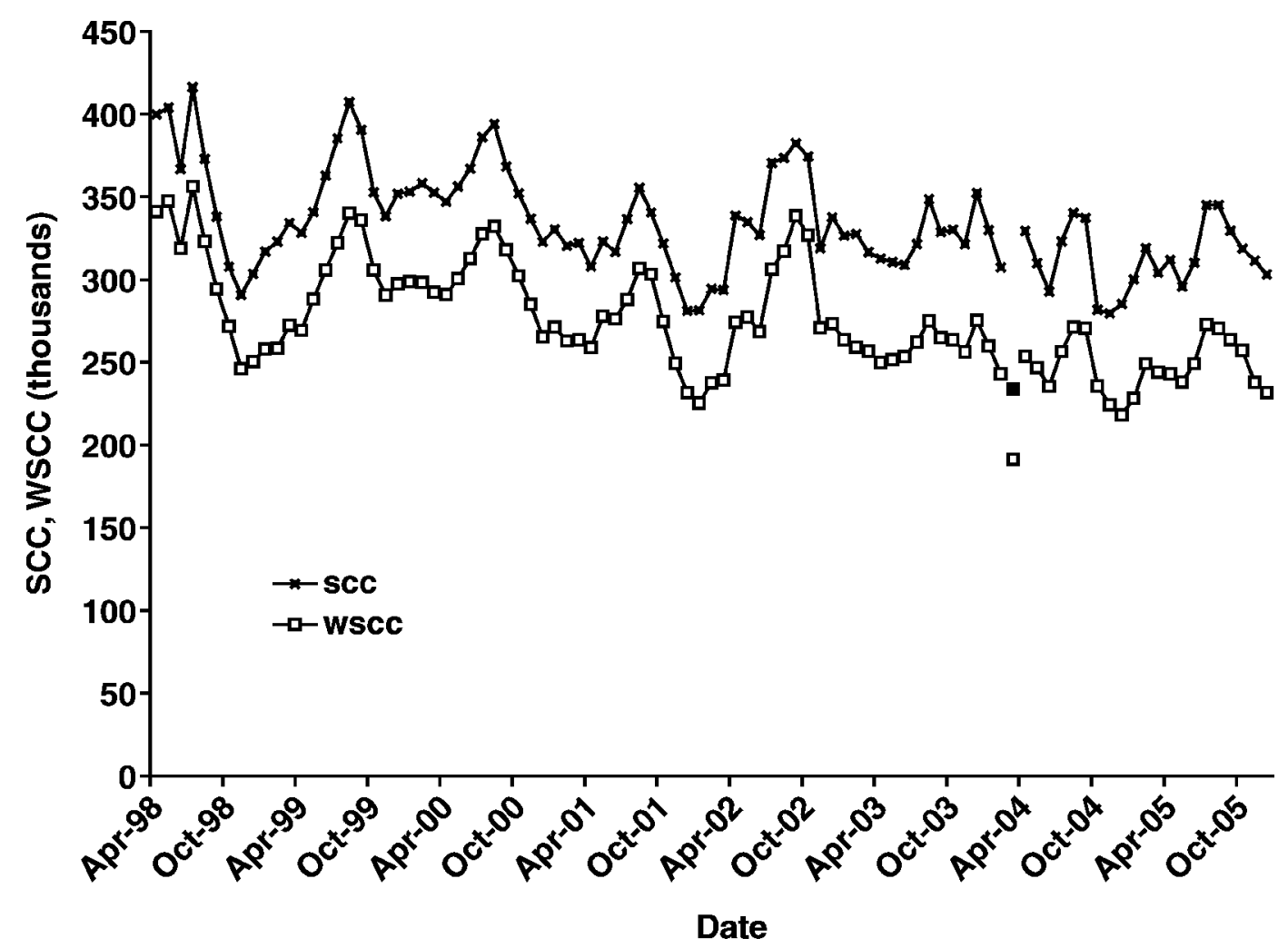

Figure 1. Time series plot for mean bulk tank SCC ( $\mathbf{a})$ and weighted bulk tank SCC (WSCC, $\square$ ) by month for the cooperative from April 1998 to December 2005. March 2004 was presented as a separate data point because it appears to be an outlier in the data.

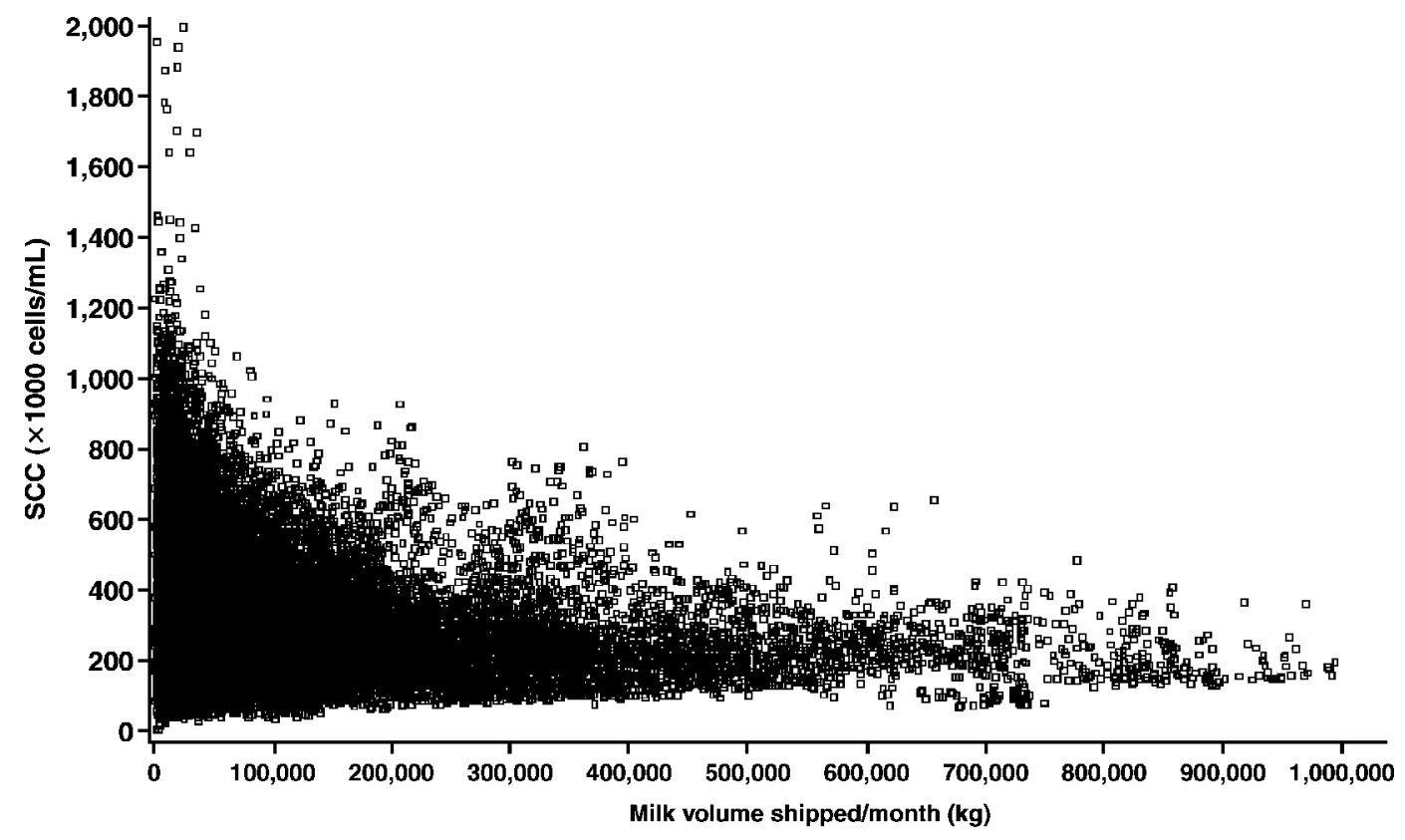

Figure 2. Scatter plot of monthly milk volume shipped and average bulk tank SCC. A total of 31,796 observations were used in this analysis. Each data point represents a producer-month. 
Table 2. Final mixed-model results for seasonality, milk production (in $1,000 \mathrm{~kg}$ ), and premium offering levels of $\$ 0.50, \$ 0.60$, and $\$ 1.00$ per hundredweight of milk relative to a premium level of $\$ 0.15$ (baseline) $)^{1}$

\begin{tabular}{lccrr}
\hline Effect & Point estimate & SD & $t$-value & $P$-value \\
\hline Intercept & 361.85 & 6.70 & 54.00 & $<0.0001$ \\
Season 1 & -15.31 & 0.92 & -16.66 & $<0.0001$ \\
Season 2 & -14.17 & 0.91 & -15.62 & $<0.0001$ \\
Milk production $(\mathrm{kg} \times 1,000)$ & -0.210 & 0.015 & -14.42 & $<0.0001$ \\
Premium $\$ 1.00 /$ cwt. & -22.55 & 2.64 & -8.55 & $<0.0001$ \\
Premium $\$ 0.60 /$ cwt. & -10.94 & 2.30 & -4.76 & $<0.0001$ \\
Premium $\$ 0.50 /$ cwt. & 0.34 & 2.29 & 0.15 & 0.8813 \\
Baseline premium $(\$ 0.15 /$ cwt. $)$ & 0.00 & & & \\
\hline
\end{tabular}

${ }^{1} \mathrm{~A}$ total of 31,796 observations were used in this analysis.

( $\$ 0.15 /$ cwt.), a premium of $\$ 1.00 /$ cwt. reduced the population mean BTSCC by 22,000 cells/mL. Mid-range premium offerings resulted in no significant change for the $\$ 0.50 /$ cwt. level, whereas an 11,000 cells $/ \mathrm{mL}$ decrease at the $\$ 0.60 /$ cwt. level was observed. This $\$ 0.60 /$ cwt. premium was introduced after the initial $\$ 1.00$ premium level. Note also that in this analysis, higher monthly milk sold (i.e., larger farms) was predictive for producing milk with lower BTSCC values.

The actual BTSCC and the linear mixed-model BTSCC predictions are shown over the study period in Figure 3. The model follows the actual data well (Akaike's information criterion, AIC reduced from 394,245 in the null model to 393,409 in the final model).
A notable exception is the lower-than-expected BTSCC at the beginning of the premium program and during the $\$ 1.00$ premium offering period.

Mean BTSCC and mean predicted BTSCC were plotted over the period of maximum premium offering from August 2001 to August 2002 together with mean BTSCC from the previous year, August 2000 to August 2001 (Figure 4). This figure shows a clear separation of mean BTSCC values during 10 of the 12 mo of maximum premium offering when compared with the previous year. Mean BTSCC for the premium period are very close to those of predicted BTSCC, which are both roughly 22,000 cells lower (average for the year) than mean BTSCC for the previous year.

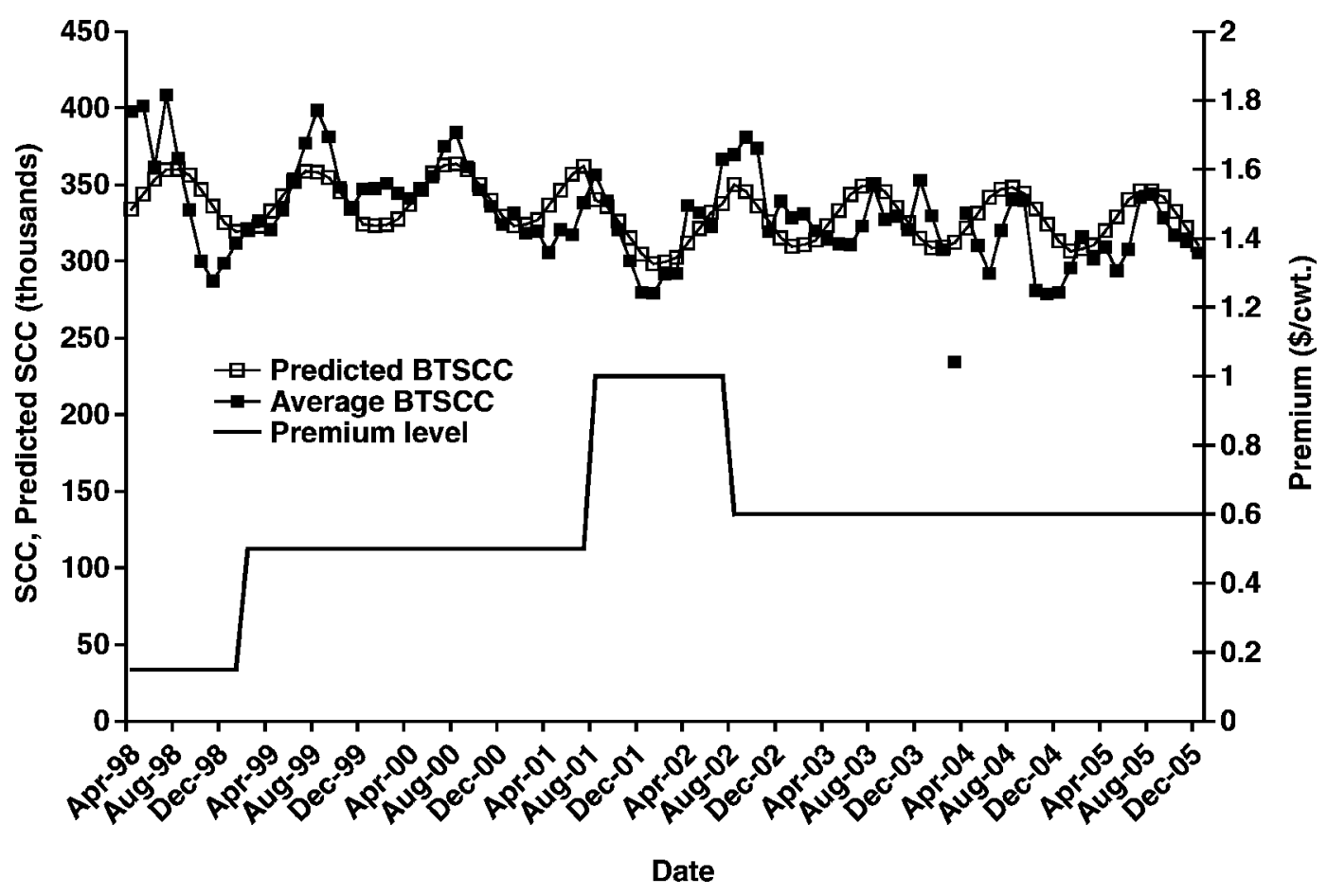

Figure 3. Time-series plot of predicted mean bulk tank SCC (BTSCC) ( $\square$ ) based on the final linear mixed model, raw mean unweighted average BTSCC ( $\mathbf{\square})$, and premium level (\$/hundredweight) by month number (-). March 2004 was presented as a separate data point as it appears to be an outlier in the data. 


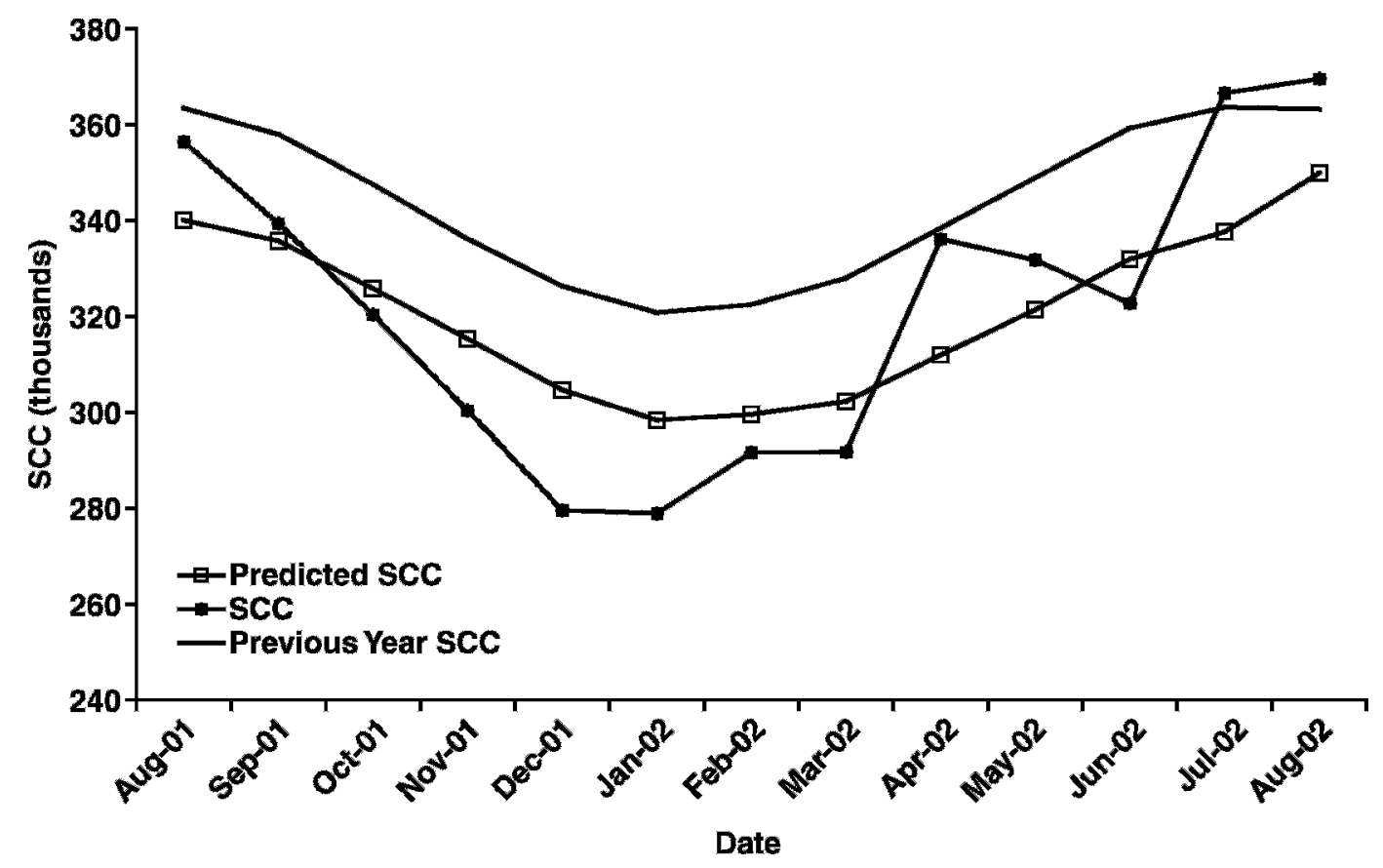

Figure 4. Mean bulk tank SCC (BTSCC) ( $\square$ ) and predicted BTSCC ( $\square$ ) during the year of maximum premium offering from August 2001 to August 2002 plotted with mean BTSCC for August 2000 to August 2001 (—). Actual mean BTSCC averaged the same as predicted BTSCC, and were both 22,000 cells below the previous year's mean BTSCC.

As shown in the results of the logistic regression analysis (Table 3) and the observed data in Figure 5, the premium structure motivated farms to produce milk with SCC below targeted BTSCC levels (100,000 cells/ $\mathrm{mL}$ in this case). Again, a premium of $\$ 0.60$ per cwt. and the high premium of $\$ 1.00$ per cwt. resulted in a significantly larger proportion of farmers delivering milk in the lowest BTSCC bracket. The Pearson goodness-of-fit $\chi^{2}$ of the final logistic regression model was 31,752 on 31,788 degrees of freedom, resulting in an excellent fit. The model results indicated that correlation within farm was approximately 0.35 , meaning that monthly milk quality results within farm were correlated (as expected). The logistic regression model showed that the amount of milk sold was a borderline significant predictor for being in the lowest BTSCC category. Relative to the mean BTSCC (Table 2), where large farms produced strongly significant lower mean BTSCC milk, farms in all size categories had a more equal probability of producing milk in the lowest BTSCC bracket and receiving the additional premium. Figure 5 presents the observed probability of farms to produce milk below either 100,000 or 200,000 cells $/ \mathrm{mL}$. The introduction of the $\$ 1.00$ premium resulted in a response with the probability of producing milk with both $<100,000$ cells $/ \mathrm{mL}$ and $<200,000$ cells $/ \mathrm{mL}$ increasing. Figure 5 still shows strong seasonality, with the probability of low BTSCC decreasing toward late sum-

Table 3. Final logistic regression model results of probability for farms to produce milk in a given month with $<100,000$ cells $/ \mathrm{mL}^{1}$

\begin{tabular}{lccrr}
\hline Effect & Point estimate & $\mathrm{SD}$ & $t$-value & $P$-value \\
\hline Intercept & -4.13 & 0.29 & -14.39 & $<0.0001$ \\
Season 1 & 0.42 & 0.06 & 7.57 & $<0.0001$ \\
Season 2 & 0.18 & 0.06 & 3.22 & 0.0013 \\
Milk production $(\mathrm{kg} \times 1,000)$ & 0.0018 & 0.0009 & 1.99 & 0.0464 \\
Premium \$1.00/cwt. & 0.66 & 0.23 & 2.85 & 0.0044 \\
Premium \$0.60/cwt. & 0.67 & 0.29 & 2.29 & 0.0220 \\
Premium \$0.50/cwt. & -0.02 & 0.23 & -0.08 & 0.9378 \\
Baseline premium $(\$ 0.15 /$ cwt.) & 0.00 & & & \\
\hline
\end{tabular}

\footnotetext{
${ }^{1}$ The Pearson $\chi^{2}$ goodness-of-fit value of this model was 31,752 on $31,788 \mathrm{df}$. A total of 31,796 observations were used in this analysis.
} 


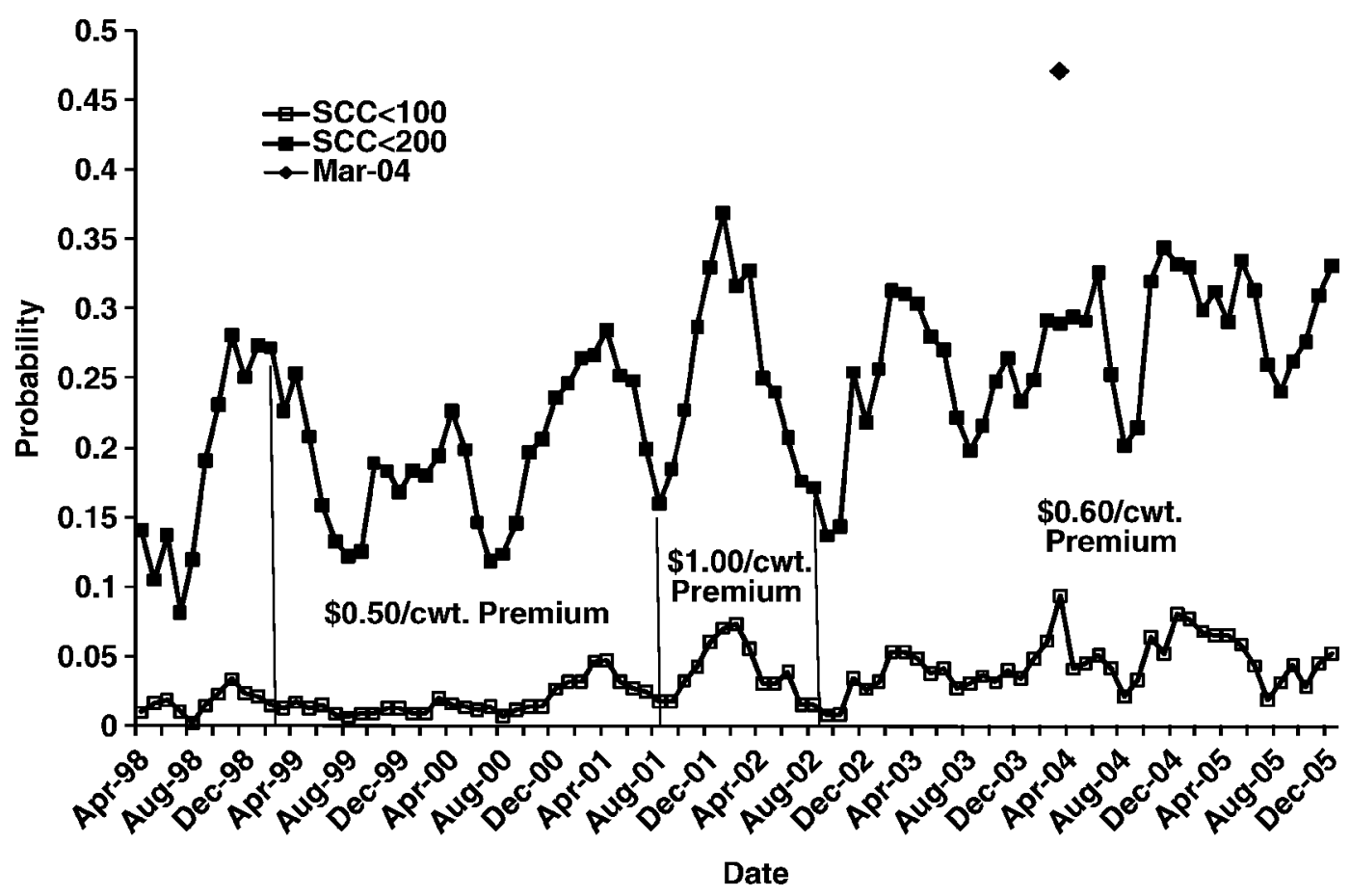

Figure 5. Percentage of farms producing milk with $<100,000$ cells $/ \mathrm{mL}$ ( $\square$ ) and $<200,000$ cells $/ \mathrm{mL}$ ( $\square$ ) per month. March 2004 was presented as a separate data point as it appears to be an outlier in the data.

mer. The subsequent $\$ 0.60$ per cwt. premium level resulted in continuous increased probability of producing low SCC milk, although the level of the $\$ 1$ premium period was not reached again, particularly with regard to the probability of producing milk with $<200,000$ cells/mL.

\section{DISCUSSION}

Our analysis showed that an aggressive premium policy is effective in reducing mean BTSCC of all milk produced for this individual cooperative. At the maximum premium level of $\$ 1.00 /$ cwt., an annual average reduction of 22,000 cells $/ \mathrm{mL}$ was observed in the total milk supply for this cooperative compared with the preprogram period. A premium of approximately $7 \%$ of the daily milk price (assuming $\$ 15.00 /$ cwt. of milk) resulted in a decrease of average BTSCC by approximately $6 \%$. The probabilities of producing milk with $<100,000$ and $<200,000$ cells $/ \mathrm{mL}$ increased to 8 and $38 \%$, respectively, a substantial increase from the probability of approximately 4 and $28 \%$ in the period before the implementation of the high premium.

The particular data set used was unique in that it contained a variable premium structure over time, with sufficient variation in premium level to be able to observe significant differences. Obviously, it is only one premium program in one cooperative. Strictly interpre- ted, it would be impossible to distinguish premium policy changes from changes in time itself. Results would be more reliable if data on multiple cooperatives with varying premium programs were available. However, the close fit to the statistical model with premium offering would suggest that premium offering is a true predictor of BTSCC.

If the principal finding of this paper holds true, a premium policy on low BTSCC milk may be an important tool in the hands of milk buyers. Optimal premium policies may be designed based on the milk quality needs of the processing facility for which the milk is purchased. Relative to penalty programs or programs that remove milk from the market above a certain BTSCC level, premium policies have the additional advantage that they have no potential disruptive effect on the overall milk supply (Adkinson et al., 2001). Studies on the actual impact of farm and total produced milk loss during a BTSCC reduction program that utilized market shut-off as its main incentive were recently performed. The study indicated that during a gradual implementation of a decreasing maximal allowable BTSCC level, no additional loss of farms or milk supply was observed relative to the periods before or after this policy change (Nightingale, 2006). It should be recognized that the current study only evaluated the premium policies of one cooperative. Hence, the variability is the within-cooperative variability and it would be 
difficult to conclude something about between-cooperative variability and the general population validity of our results.

Efforts to lower population SCC in the milk pool should be directed to farms that are chosen not solely on a producer's mean bulk tank BTSCC, but rather based on the combination of BTSCC and the associated milk production of the dairy farm. This more accurately portrays a producer's actual contribution to a processing plant's SCC. We have previously reported that the highest contributors to population SCC are those producers in BTSCC categories from 400,000 to 750,000 cells/mL (Schukken et al., 1992b). These farms tend to produce more milk than the very high BTSCC farms (note BTSCC $>750,000$ is only rejected after multiple cell count violations), and on a per-farm basis, interventions would be more effective in this group of dairies. In this data set we had no access to actual management procedures that changed in response to a higher premium.

Quality premiums proved to be an effective tool in influencing milk quality and were particularly attractive for large producers on the fringe of a premium eligible BTSCC category. As we showed in the mean BTSCC model (Table 2), large farms tend to produce milk with lower mean BTSCC. However, this herd size effect was much smaller in the logistic regression model on the actual probability of being in the BTSCC bracket below 100,000 (Table 3). Figure 2 illustrates this further, and indicates that both the very highest and the very lowest BTSCC values are produced by relatively small farms. Large dairies show less variability and tend to be more stable around the mean. In contrast, small dairies have large variability and parameters (such as BTSCC) may vary from very high to very low.

Applied economic research into the effects of "carrot vs. stick" approaches in motivating individuals indicated that rewards alone are relatively ineffective. Punishments improved cooperation; however, combining rewards and punishments had the strongest effect (Andreoni et al., 2003). These findings complement our simulation studies, which also indicated that rewards and punishments act to complement one another (Schukken et al., 1992b). Of course there are some semantics in this; penalty programs for higher BTSCC levels are at the same time rewarding lower BTSCC levels (levels below the cut-off for "high"). In this study we have used premium programs to indicate a premium for very low BTSCC levels. It is not motivationally correct to interpret the premium program used by this cooperative as a penalty program for BTSCC levels above 100,000 cells $/ \mathrm{mL}$.

We conclude from these data that milk buyers can improve milk quality in the supplying dairy farms. Pre- vious studies have shown the impact of penalty programs on population mean BTSCC (Sargeant et al., 1998), but this study is the first to report on a premium approach to lower BTSCC. It became clear from our data that only relatively high premium levels offer enough incentive to lower mean population cell counts. Results from our previous simulations combined with studies on motivation in economic research would indicate that a combination of a penalty program for high BTSCC and a premium program for low BTSCC would be most effective in reducing population BTSCC levels.

\section{ACKNOWLEDGMENTS}

We would like to acknowledge Upstate-Niagara Cooperative Inc. (Buffalo, NY) that graciously provided us with their milk quality data.

\section{REFERENCES}

Adkinson, R. W., R. H. Gough, R. Graham, and A. Yilmaz. 2001. Implications of proposed changes in bulk tank somatic cell count regulations. J. Dairy Sci. 84:370-374.

Andreoni, J., W. Harbaugh, and L. Vesterlund. 2003. The Carrot or the stick: Rewards, punishments, and cooperation. Am. Econ. Rev. 93:893-902.

Barbano, D. M., Y. Ma, and M. V. Santos. 2006. Influence of raw milk quality on fluid milk shelf life. J. Dairy Sci. 89(E Suppl.):E15-E19.

Grohn, Y. T., J. J. McDermott, Y. H. Schukken, J. A. Hertl, and S. W. Eicker. 1999. Analysis of correlated continuous repeated observations: Modelling the effect of ketosis on milk yield in dairy cows. Prev. Vet. Med. 39:137-153.

Hogan, J. 2005. Human health risks associated with high BTSCC milk: Symposium overview. Pages $73-75$ in Proc. 44th NMC Annu. Mtg. Natl. Mastitis Counc. Inc., Verona, WI.

Hortet, P., and H. Seegers. 1998. Calculated milk production losses associated with elevated somatic cell counts in dairy cows: Review and critical discussion. Vet. Res. 29:497-510.

Jayarao, B. M., and D. R. Henning. 2001. Prevalence of foodborne pathogens in bulk tank milk. J. Dairy Sci. 84:2157-2162.

Klei, L., J. Yun, A. Sapru, J. Lynch, D. Barbano, P. Sears, and D. Galton. 1998. Effects of milk somatic cell count on cottage cheese yield and quality. J. Dairy Sci. 81:1205-1213.

Nightingale, C. 2006. Economic impacts and influences of milk quality. Master's Thesis. Kansas State University, Manhattan.

Ruegg, P. L., and T. J. Tabone. 2000. The relationship between antibiotic residue violations and somatic cell counts in Wisconsin dairy herds. J. Dairy Sci. 83:2805-2809.

Sargeant, J. M., Y. H. Schukken, and K. E. Leslie. 1998. Ontario bulk milk somatic cell count reduction program: Progress and outlook. J. Dairy Sci. 81:1545-1554.

SAS Institute. 2006. SAS Online Doc 9.1.3. SAS Institute Inc., Cary NC.

Saville, W. J., T. E. Wittum, and K. L. Smith. 2000. Association between measures of milk quality and risk of violative antimicrobial residues in grade-A raw milk. J. Am. Vet. Med. Assoc. 217:541-545.

Schukken, Y. H., J. Buurman, A. Brand, D. Vandergeer, and F. J. Grommers. 1990. Population dynamics of bulk milk somatic cell counts. J. Dairy Sci. 73:1343-1350.

Schukken, Y. H., Y. T. Grohn, B. McDermott, and J. J. McDermott. 2003. Analysis of correlated discrete observations: Background, examples and solutions. Prev. Vet. Med. 59:223-240.

Schukken, Y. H., K. E. Leslie, A. J. Weersink, and S. W. Martin. 1992a. Ontario bulk milk somatic cell count reduction program.1. 
Impact on somatic cell counts and milk quality. J. Dairy Sci. 75:3352-3358.

Schukken, Y. H., K. E. Leslie, A. J. Weersink, and S. W. Martin. 1992b. Ontario bulk milk somatic cell count reduction program. 2. Dynamics of bulk milk somatic cell counts. J. Dairy Sci. 75:3359-3366.

Seegers, H., C. Fourichon, and F. Beaudeau. 2003. Production effects related to mastitis and mastitis economics in dairy cattle herds. Vet. Res. 34:475-491.
Straley, B. A., S. C. Donaldson, N. V. Hedge, A. A. Sawant, V. Srinivasan, S. P. Oliver, and B. M. Jayarao. 2006. Public health significance of antimicrobial-resistant gram-negative bacteria in raw bulk tank milk. Foodborne Pathog. Dis. 3:222-233.

Wilson, D. J., R. N. Gonzalez, J. Hertl, H. F. Schulte, G. J. Bennett, Y. H. Schukken, and Y. T. Grohn. 2004. Effect of clinical mastitis on the lactation curve: A mixed model estimation using daily milk weights. J. Dairy Sci. 87:2073-2084. 